\title{
TIRE SEUS ÓCULOS
}

\author{
León Denis Fereira Xavier ${ }^{1}$
}

Universidade de São Paulo (USP), São Paulo, Brasil

tire seus óculos

pare de ver o seu mundo

para compreender

para sentir o Mundo

esqueça o que você conhece

parta para novas experiências

repense toda certeza da sua existência

é assim que a gente cresce

tire seus óculos

para encontrar um novo lugar

para encontrar uma nova cultura

para, enfim, se encontrar

esqueça o que você conhece

seus conhecimentos eurocentrados

seus pensamentos bem demarcados

é assim que a gente cresce

tire seus óculos

limpe sua vista

abra os olhos

a vida não é uma eterna conquista

esqueça o que você conhece

e mais uma vez

tire seus óculos

é assim que a gente cresce

\footnotetext{
${ }^{1}$ Graduado em Geografia Licenciatura pela Universidade Federal do Ceará (UFC). Atualmente é mestrando em Integração da América Latina pela Universidade de São Paulo (USP). E-mail: leonxavier@usp.br
} 
Recebido em 13/07/2021.

Aceito em 08/12/2021.

Publicado em 15/12/2021. 